\title{
Az Európai Újraélesztési Társaság (ERC) 2021. évi posztreszuszcitációs időszak ellátásáról szóló ajánlásának összefoglaló bemutatása
}

\author{
Schiszler Bence, Priskin Gábor, \\ Pécsi Tudományegyetem Egészségtudományi Kar, Sürgősségi Ellátási és Egészségpedagógiai Intézet, \\ Oxyológiai, Sürgősségi Ellátási Tanszék \\ Pandur Attila, Tóth Balázs \\ Pécsi Tudományegyetem Egészségtudományi Kar, Sürgősségi Ellátási és Egészségpedagógiai Intézet, \\ Oxyológiai, Sürgősségi Ellátási Tanszék, Pécsi Tudományegyetem Egészségtudományi Doktori Iskola \\ Prof. Dr. Betlehem József, \\ Pécsi Tudományegyetem Egészségtudományi Kar, Sürgősségi Ellátási és Egészségpedagógiai Intézet \\ Dr. Radnai Balázs, \\ Pécsi Tudományegyetem Egészségtudományi Kar, Sürgősségi Ellátási és Egészségpedagógiai Intézet, \\ Oxyológiai, Sürgősségi Ellátási Tanszék
}

\section{Bevezetés}

Az European Resuscitation Council (ERC) az European Society of Intensive Care Medicine (ESICM) közremüködésével 2015-ben egységesítette a spontán keringés visszatérés (ROSC) utáni posztreszuszcitációs teendőket, mely közlésre került a Resuscitation and Intensive Care Medicine folyóiratban. A következőkben tárgyalt, 2021-ben kiadott felnőtt posztreszuszcitációs ajánlás a 2015. évi guideline alapjain nyugszik, azonban kiegészült az elmúlt 5 évben folytatott, a témában releváns kutatások eredményeivel. Jelen referátum célja, hogy összefoglalja az ajánlás szerint, e témába vágóan megfogalmazott sarokpontokat, úgy mint a beteg oxigenizációja és lélegeztetése, koronária angiográfia, vérnyomás kontroll, terápiás maghőmérséklet kontroll, görcstevékenységek kontrollálása, intenzív terápiás ellátás, prognosztika a túlélés tekintetében, és a rehabilitáció.

Számos tanulmány számolt be arról, hogy ROSC-ot követően hatékony posztreszuszcitációs ellátás szükséges ahhoz, hogy pozitív prognosztikai eredményekről lehessen beszámolni a túlélési esélyek kapcsán. (1-4) Ehhez az eredményes posztreszuszcitációs ellátáshoz fogalmaz meg az új ajánlás egy 5 pontól álló kulcsüzenetet, mely a következőket foglalja magába:

a) ROSC-ot követően használjuk az ABCDE betegvizsgálati módszert, törekedjünk a

- megfelelő légútbiztosításra (ETI/SGE)
- $\mathrm{SpO}_{2}: 94-98 \%$

- Normokapnia tartására

- Normovolémia biztosítására

- SBP>100 Hgmm

b) Ajánlott azonnal koronária katéteres laborba szállítani a beteget, ha kardiális eredet feltételezett és/vagy ST eleváció tapasztalható az EKG-n.

c) Alkalmazzuk a célzott testhő kontrollt (TTM) felnőttek esetében OHCA és IHCA esetén az iniciális ritmustól függetlenül, ha ROSC-ot követően eszméletlen állapotban vannak.

d) Alkalmazzunk kombinált neuro-prognosztikai vizsgálatot.

e) Értékeljük a fizikai és pszichikai károsodásokat kórházi elbocsátás előtt és történjen utánkövetés legalább 3 hónapon keresztül. Szükség szerint egyéb szakellátásra történő utalás javasolt.

\subsection{Légútbiztosítás, és lélegeztetés ROSC-ot követöen}

ROSC-ot követően a betegek döntő többsége csökkent tudati szinttel rendelkezik, ezért ha a CPR során még nem történt meg, szükség van a megfelelö légútbiztosításra. Amennyiben az ellátó kompetenciaszintje megengedi, úgy az endotrachealis intubáció (ETI) jelenti a legmegfelelőbb légútbiztosítást, ennek 
hiányában a supraglottikus eszközök (SGE) használata javasolt. Összességében az ajánlás a következőkre hívja fel a figyelmet:

\section{Oxigenizáció tekintetében}

- Amint lehetőség van rá, az artériás vér oxigén megbízható nyomon követese mellett (pulzoxymetria, vérgázanalízis) javasolt 100\%-os oxigén adása, bármely ROSC-ot követően felnőttek esetén.

- Javasolt a hypoxaemia elkerülése felnőtt esetén ROSC után.

- Javasolt a hyperoxaemia elkerülése felnőtt esetén ROSC után.

\section{Lélegeztetés vezérlése tekintetében}

- Javasolt a kapnográfia használata.

- Javasolt a normokapnia (PaCO2=35-45 Hgmm) elérése és/vagy fenntartása ROSC-ot követően, felnőtt esetén.

\subsection{Keringés}

A keringésmegállások hátterében sok esetben kardiovaszkuláris megbetegedés jelölhető meg kórokként, mint pl. akut koronária szindróma (ACS). A 2015-ben kiadott ajánlás a minél előbbi koronária festést és szükség esetén az azonnali percutan coronaria intervenció (PCI) alkalmazását egyértelműen meghatározta abban az esetben, amennyiben ROSC-ot követően ST eleváció tapasztalható a 12 elvezetéses EKG regisztrátumon. ROSC-ot követően ST eleváció hiányában a korábbi ajánlás, csak megfontolás szintjén említi a koronarográfia eshetőségét, mivel a korábbi tanulmányok adatai ellentmondónak bizonyultak ST eleváció hiányában a sürgős koronária festés potenciális előnyei tekintetében. A 2021-es protokoll azt javasolja, hogy abban az esetben, ha ROSC-ot követően nem tapasztal az ellátó a 12 elvezetéses EKG-n ST elevációt, azonban a klinikai jelek alapján haemodinamikai és/vagy elektromos instabilitást gyanít a betegnél, úgy ajánlott a katéteres laborba való szállítás. Ennek alapja, egy randomizált kontrollált vizsgálat (RCT) mely rávilágított arra, hogy a 90-napos túlélés tekintetében nem volt különbség az ST eleváció hiányában, ROSC-ot követően azonnal és a halasztva elvégezett coronarographia között. A kutatásban vizsgált eseteknél a betegek iniciális ritmusa kamrafibrilláció volt. $(5,6)$

\section{Hemodinamikai támogatás}

ROSC-ot követően bizonyos mértékủ miokardiális diszfunkció több, mint 60\%-ban megfigyelhető a betegeknél, mely kifejlődésének hátterében sokszor akut miokardiális infarktus (AMI) áll, ami az arrest állapot kialakulásáért is felelös lehet. A korai echokardiográfia használatával azonosítható a diszfunkció súlyosságának mértéke, és segítségével elösegíthető a hemodinamikai támogatást szolgáló stratégia tervezése.

Szükséges a folyamatos artériás vérnyomásmérés, és annak nyomon követese, annak érdekében, hogy elkerüljük a hipotenziót. A hipotenzió elkerülése céljából gondoskodni kell a az artériás középnyomás $65 \mathrm{Hgmm}$ feletti tartásáról, és célzottan annak ideális mértékére kell törekedni a megfelelő óradiurézis $(0,5 \mathrm{ml} / \mathrm{kg} / \mathrm{h})$ és normális vagy csökkent laktátszint biztosításával. Bradikardia esetén, annak kezelése nem szükséges, ha a célzott testhő kontrollt alkalmazunk (TTM $33 \mathrm{C}^{\circ}$ ) és megfelelő a beteg vérnyomása, laktát szintje, $\mathrm{ScvO}_{2}$, és $\mathrm{SvO}_{2}$-je, azonban, ha az említett értékek elégtelenek, megfontolandó a maghőmérséklet emelése legfeljebb $36^{\circ} \mathrm{C}$-ig. Bizonyos esetekben keringéstámogatásra lehet szükség, hogy a megfelelő perfúziót fenn tudjuk tartani. Ebből a célból a protokoll a noradrenalin vagy dobutamin alkalmazását ajánlja akkor, ha a folyadékbólusok intravénás adása hatástalan, vagy kontraindikált. Gyógyszerek tekintetében elmondható, hogy arreszt állapotot követően, a posztreszuszcitációs szakban nem ajánlott a szteroidok rutinszerü alkalmazása, és kerülendő a hypokalémia, ami esetlegesen malignus ritmuszavart indukálhat. Abban az esetben, ha a betegnél az alkalmazott terápia ellenére is fennáll pl. bal kamrai diszfunkció, kardiogén shock, egyéb hemodinamikai instabilitás, ACS, rekurrens kamrai tachikardia (VT) vagy kamrafibrilláció (VF) úgy megfontolandó a mechanikus keringéstámogatás Extracorporeal Membrane Oxygenation (ECMO) segítségével.

\section{A neurológiai kimenetel optimalizálása}

\subsection{Görcsgátlás}

Kardiális eredetű arreszt állapot esetén az esetek 20-30\%-nál tapasztalható konvulzió, mely általában súlyos agyi hipoxiás jelként detektálható. Leggyakrabban mioklónus formájában jelenik meg, de 
a generalizált és fokális tónusos-klónusos görcsrohamok megjelenése is gyakori. A klinikai kép mellett az elektroenkephalongram-on (EEG) látható kóros aktivitás is utalhat a zajlására, mely segítheti a görcstevékenység epileptiform eredetének tisztázását. Konvulzió esetén az agyi metabolikus aktivitás fokozódik, ami jelentősen rontja a kimenetelt, így mielőbbi hatékony görcsgátlásra van szükség. A protokoll alapján a levetiracetam vagy a nátrium valproate az élvonalbeli antikonvulzív szer az antiepileptikumok és szedatívumok mellett, ugyanakkor rutinszerű alkalmazásuk nem javasolt, pusztán a konvulzió kialakulásának kivédése céljából. Elmondható tehát, hogy javasolt az EEG alkalmazása a görcsrohamok differenciáldiagnosztikájához, illetve ajánlott a folyamatos monitorozása a posztreszusztitációs kezelés hatásosságának megfigyelése céljából.

\subsection{Hőmérséklet kontroll}

Állat és humán kutatások körében végzett metaanalízis bizonyította a terápiás hypotermia alkalmazásának neurológiai kimenetelt javító hatását CPR-en átesett, eszméletlen felnőtt ROSC betegeknél. $(7,8)$ A neuroprotektív hatása sokrétű, ugyanis csökken az agyi metabolikus ráta, ezáltal az ischaemiás területek oxigénigénye, illetve membránstabilizáló hatása révén antiepileptogén effektussal is rendelkezik, melylyel tovább csökken a sejtkárosodás mértéke.

A 2015. évi ERC ajánláshoz képest változatlanul megmaradtak a következő javaslatok a 2021-es protokollban:

- A hőmérséklet kontroll során tartsunk fent állandó, 32-36 fokos maghőmérsékletet. (erős ajánlás közepes szintű evidencia) A betegcsoportok tekintetében, hogy kik profitálhatnak a 32-34 foknál alacsonyabb, vagy a 36 foknál magasabb testhőmérsékletből, annak kiderítésére további vizsgálatok elvégzése szükséges.

- Célzott testhőkontroll (TTM) javasolt azon felnőtt betegek esetén, akiknél prehospitálisan az első észlelt ritmus sokkolandó volt, és ROSC-ot követően eszméletlen állapotban vannak. (erős ajánlás, alacsony szintü evidencia)

- Célzott testhőkontroll javasolt azon felnőtt betegek esetén is, akiknél prehospitálisan az első észlelt ritmus nem sokkolandó volt, és ROSC-ot követően eszméletlen állapotban vannak. (gyenge ajánlás, nagyon alacsony szintű evidencia)
- Célzott testhőkontroll javasolt továbbá azon felnőtt betegek esetén, akik az első észlelt ritmustól függetlenül intrahospitálisan, ROSC-ot követően eszméletlen állapotban vannak. (gyenge ajánlás, nagyon alacsony szintü evidencia)

- Ha célzott testhőkontrollt alkalmaztunk, azt tartsuk fenn legalább 24 óráig. (gyenge ajánlás, nagyon alacsony szintü evidencia)

ROSC-ot követően gyakran fordul elő hipertermiás periódus, ami a neurológiai kimenetel szempontjából káros hatásokkal bír. A posztreszuszcitációs ellátás során, kerülni kell a láz kialakulását, vagyis nem szabad, hogy a beteg maghőmérséklete $37,7^{\circ} \mathrm{C}$ fok fölé emelkedjen a ROSC-ot követő legalább 72 órában. Tanulmányok ugyanakkor rávilágítottak arra, hogy kerülendő prehospitálisan a hütött infúziók intravénás adagolása, tehát az aktív külső hütés preferálandó a hipertermia kivédése céljából. A célzott testhőkontrollra vonatkozóan egyáltalán nem, vagy csak kevésellenjavallat fogalmazható meg, ugyanakkor súlyos kardiovaszkuláris megbetegedés esetén a maghőmérsékletet ajánlott $33^{\circ} \mathrm{C}$ felett tartani ROSC-ot követően eszméletlen felnőtt betegnél.

\section{Intenzív terápiás ellátás}

Reszuszcitációt követően azon betegeknél, akik komatózus állapotban vannak, el kell végezni a neurológiai prognosztikai vizsgálatokat klinikai-, elektrofiziológiai- (EEG, SSEP) és képalkotó vizsgálatok (CT/MRI), továbbá biomarkerek (NSE) segítségével, a túlélési esélyek megítélése céljából. Kombinált neuro-prognosztikai stratégia ajánlott, mivel önmagában egyik vizsgálat sem nyújt kellő megbízhatóságot. Mivel a klinikai neurológiai vizsgálatok kulcsszerepet töltenek be a prognosztikában, az álpozitív eredmények elkerülése miatt rövid hatású szedatívumok és kábító fájdalomcsillapítók alkalmazása javasolt. Amennyiben célzott testhőkontroll alkalmazása zajlik a betegnél, úgy relevánsan csak annak befejeztével lehet a prognosztikára irányuló vizsgálatokat elvégezni.

RCT pilot vizsgálatok rávilágítottak arra, hogy az izomrelaxánsok alkalmazása nem nyújt akkora előnyt a túlélés szempontjából, mint azt korábban jegyezték (hipoxémia-t és ARDS-t kivéve), ezért rutinszerü 
alkalmazását a protokoll nem javasolja (9), alkalmazása ugyanakkor megfontolandó abban az esetben, ha didergés tapasztalható a betegnél. Hasonló RCT vizsgálatok eredményei alapján javasolják a profilaktikus antibiotikum adásának kerülését, hiszen jelenleg bizonytalan eredményekkel rendelkeznek annak kimenetelre való hatásáról. (10) Metaanalitikus vizsgálat eredménye alapján ugyanakkor a stressz-fekély profilaxis ajánlott, különösen antikoagulált betegek körében, hiszen alkalmazásával elkerülhető a gasztrointesztinális vérzés kialakulása. A posztreszuszcitációs szakban az intenzív kezelésre szoruló betegek esetén szükséges a mélyvénás trombózis profilaxis, az esetleges szövődmények kialakulásának kivédése céljából. A vércukorszint tekintetében a 2015-ben megjelent ajánlásban megfogalmazottak pontosításra kerültek jelen protokollban, melynek értelmében törekedni kell annak 7,8-10 mmol/l közti szinten történő tartásáról.

A posztreszuszcitációs szak bármely fázisában történő professzionális ellátás a tulajdonképpeni meghatározója annak, hogy milyenek lesznek a beteg életkilátásai, illetve jó prognosztika esetén nagymértékben befolyásolja a hospitalizáció idejét. Az intenziv terápiás ellátást követően megkezdhető a beteg rehabilitációjának tervezése és megvalósítása. A protokoll a rehabilitáció tekintetében az 1. ábra szerinti ajánlatokat teszi:



1. ábra Kórházi elbocsájtás elötti/utáni teendók posztreszuszcitációt követöen

\section{Prognosztika}

\subsection{Klinikai vizsgálat}

Azoknál a betegeknél, akiknél ROSC-ot követően 72 óra vagy azon túl komatózus állapot áll fenn (GCS motoros válasz $\leq 3$ ), a következő klinikai vizsgálatok eredményei jelezhetik előre az alacsony neurológiai kimenetelt:

- bilaterálisan hiányzó pupilla fényreakció 72 órán túl

- bilaterálisan hiányzó korneareflex 72 órán túl

- ROSC-ot követő 96 órán belül ismétlődő mioklónus, különös tekintettel a státusz mioklónusra 72 órán belül.

\subsection{Neurofiziológia}

ROSC-ot követően minden komatózus betegnél javasolt az EEG és a szomatoszenzoros kiváltott potenciál (SSEP) vizsgálatok elvégzése és monitorozása, a célzott testhőkontroll befejezését követően. Fontos hangsúlyozni, hogy a szedatívumok és kábító fájdalomcsillapítók befolyásolhatják a vizsgálat eredményeit. ROSC-ot követő 72 órán belül az EEG-n tapasztalható malignus rohamok, illetve 24 órán vagy azon túl nem kiváltható SSEP egyértelműen rossz prognosztikára utalnak.

\subsection{Biomarker vizsgálat}

ROSC-ot követően a neuron specifikus enolase (NSE) meghatározott időközönkénti mérése iránymutató lehet a prognosztika szempontjából. A meghatározást a 24. 48. és 72. órában szükséges elvégezni. Abban az esetben, ha a 48. és a 72. órában mért NSE emelkedést mutat, rossz prognózisra lehet számítani a neurológiai kimenetel tekintetében.

\subsection{Képalkotás}

Kardiális okú arreszt állapotot követően a posztreszuszcitációs szakban szükség lehet a CT/MRI képalkotó vizsgálatok elvégzésére annak megállapítása érdekében, hogy tapasztalható-e kiterjedt anoxiás agyi károsodás generalizát agyi ödéma megjelenése következtében. A hatékony prognosztika érdekében a képalkotó vizsgálatok eredményeit össze kell vetni, és együtt kell értékelni a többi, elvégzett vizsgálat eredményeivel. 
A kombinált neuroprognosztikai eljárás menetét a 2 . ábra foglalja össze:



\subsection{Szervdonáció}

A kombinált neuro-prognosztikai vizsgálat eredményei alapján megjósolható, hogy milyen életkilátásai vannak a betegnek a túlélés, illetve a felépülés szempontjából. Abban az esetben, ha a vizsgálati eredmények függvényében rossz prognosztikáról lehet beszámolni, úgy felvetődhet a szervdonáció eshetősége, melynek menetét a protokoll a 3 . ábra alapján határozza meg:

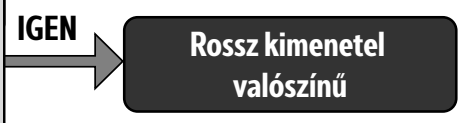

2. ábra A neuroprognosztika folyamata




A posztreszuszcitációs ellátás összehasonlitása a 2015-ös és 2021-es

ERC guideline alapján, a föbb kiegészítések tekintetében.

2015-ben megjelent protokoll

2021-ben megjelent protokoll

\section{Koronária angiográfia}

- ROSC-ot követően 12 elvezetéses EKG-n ST eleváció látható.

- Gyanú áll fenn a kardiális eredetre
- Prehospitálisan ROSC-ot követően ST eleváció hiányában megfontolandó, ha nagy esély van kardiális eredetre (pl: haemodinamikai és/vagy elekrtomos instabilitás)

\section{Vérnyomás célérték}

- Célzottan az ideális artériás középnyomást kell elérni a megfeleló óradiurézis $(1,0 \mathrm{ml} / \mathrm{kg} / \mathrm{h})$ és normális vagy csökkent laktátszint beállításával.
- A hipotenzió elkerülése céljából gondoskodni kell a vérnyomás $65 \mathrm{Hgmm}$ feletti tartásáról, és célzottan az ideális artériás középnyomást kell elérni a megfelelő óradiurézis $(0,5 \mathrm{ml} / \mathrm{kg} / \mathrm{h})$ és normális vagy csökkent laktátszint beállításával.

\section{Görcsgátlás}

- nátrium valproate, levetiracetam, phenytoin, benzodiazepinek, propofol, barbiturátok alkalmazása
- levetiracetam vagy nátrium valproate használata antiepileptikumok és szedatívumok mellett

\section{Hőmérséklet kontroll}

- A hőmérséklet kontroll során tartsunk fent állandó, 32-36 fokos maghőmérsékletet

- A betegcsoportok tekintetében, hogy kik profitálhatnak a $32-34{ }^{\circ} \mathrm{C}$ alacsonyabb, vagy a $36^{\circ} \mathrm{C}$ magasabb testhőmérsékletből, annak kiderítésére további vizsgálatok elvégzése szükséges.

- Célzott testhőkontroll (TTM) javasolt azon felnőtt betegek esetén, akiknél prehospitálisan az első észlelt ritmus sokkolandó volt, és ROSC-ot követően eszméletlen állapotban van.

- Célzott testhőkontroll javasolt azon felnőtt betegek esetén, akiknél prehospitálisan az első észlelt ritmus nem sokkolandó volt, és ROSC-ot követően eszméletlen állapotban van.

- Célzott testhőkontroll javasolt azon felnőtt betegek esetén, akiknél az első észlelt ritmustól függetlenül intrahospitálisan, ROSC-ot követően eszméletlen állapotban van.

- Ha célzott testhőkontrollt alkalmaztunk, azt tartsuk fenn legalább 24 óráig.
- Célzott testhőkontroll javasolt pre- és intrahospitálisan, kardiális eredetü ROSC-ot követően minden eszméletlen felnőtt betegnél, függetlenül attól, hogy az iniciális ritmus sokkolandó, vagy nem sokkolandó volt.

- A terápiás célérték $32-36^{\circ} \mathrm{C}$ között legyen az első 24 órában.

- ROSC-ot követően komatózus beteg esetén kerüljük a lázat $\left(>37,7^{\circ} \mathrm{C}\right)$ az első 72 órában

\section{Intenzív terápiás ellátás}

- Rövid hatású narkotikumok alkalmazása (pl: propofol, alfentanil, remifentanil)

- Vércukorszint legyen $\leq 10 \mathrm{mmol} / \mathrm{l}$, kerüljük a hipoglikémiát.
- Rövid hatású szedatívumok és narkotikumok alkalmazása.

- Kerüljük az izomrelaxánsok alkalmazását, azonban didergés esetén megfontolható.

- Stresszfekély profilaxis alkalmazása

- Mélyvénás trombózis profilaxis alkalmazása

- Vércukorszint legyen 7,8-10 mmol/l közt, alkalmazzunk inzulint infúzió formájában amennyiben szükséges

- Kerüljük a hipoglikémiát

- Rutinszerü antibiotikumos kezelés nem javasolt

\section{Prognosztika}

- Hiányzó pupilla, kornea reflex

- Hiányzó bilaterális SSEP

- Státus mioklónus $\leq 48 \mathrm{~h}$ belül ROSC után

- Magas NSE szint

- Malignus EEG aktiváció

- Diffúz anoxiás agysérülés CT/MRI alapján
- GCS motoros válasz $\leq 372$ h keresztül

- Hiányzó pupilla, kornea reflex $72 \leq \mathrm{h}$ követően

- Hiányzó bilaterális SSEP $\geq 24$ h-át

- Malignus EEG aktiváció $\geq 24$ h-át

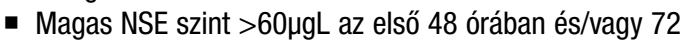
órában

- Státus mioklónus $\leq 72 \mathrm{~h}$ belül

- Diffúz anoxiás agysérülés CT/MRI alapján 
A posztreszuszcitációs ellátást a 2021. évi protokoll a 4. ábra szerinti algoritmus alapján foglalja össze:

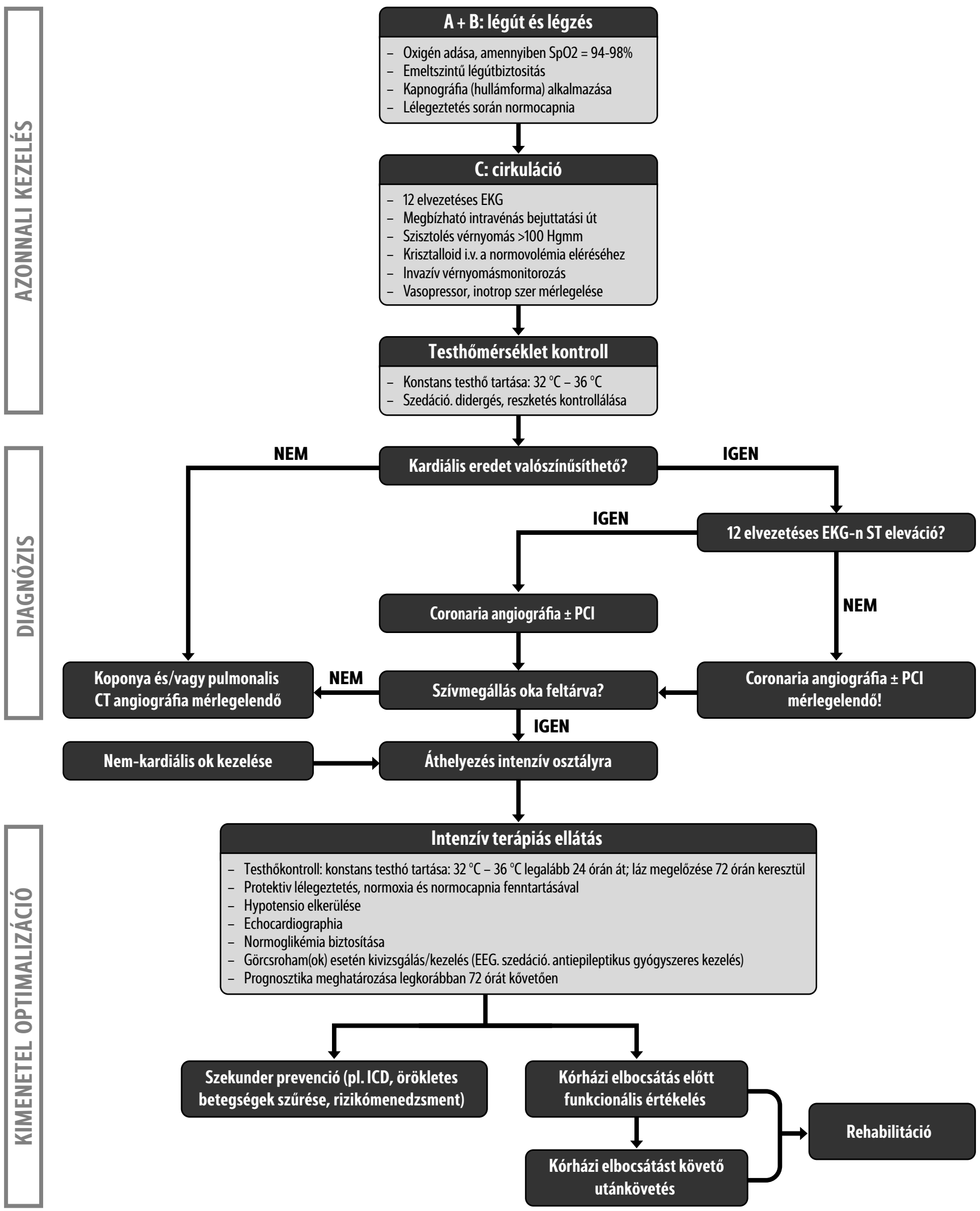

4. ábra Posztreszuszcitációs ellátás folyamatábra 


\section{Irodalomjegyzék}

1. Nolan JP, Neumar RW, Adrie C, et al. Post-cardiac arrest syndrome: epidemiology, pathophysiology, treatment, and prognostication. A Scientific Statement from the International Liaison Committee on Resuscitation; the American Heart Association Emergency Cardiovascular Care Committee; the Council on Cardiovascular Surgery and Anesthesia; the Council on Cardiopulmonary, Perioperative, and Critical Care; the Council on Clinical Cardiology; the Council on Stroke. Resuscitation 2008;79:350-79

2. Mongardon N, Dumas F, Ricome S, et al. Postcardiac arrest syndrome: from immediate resuscitation to longterm outcome. Ann Intensive Care 2011;1:45,

3. Stub D, Bernard S, Duffy SJ, Kaye DM. Post cardiac arrest syndrome: a review of therapeutic strategies. Circulation 2011;123:1428-35

4. Sekhon MS, Ainslie PN, Griesdale DE. Clinical pathophysiology of hypoxic ischemic brain injury after cardiac arrest: a "two-hit" model. Crit Care 2017;21:90, doi:http://dx.doi.org/10.1186/s13054-017-1670-9.

5. Soar J, Donnino MW, Maconochie I, et al. 2018 international consensus on cardiopulmonary resuscitation and emergency cardiovascular care science with treatment recommendations summary. Resuscitation 2018;133:194-206

6. Soar J, Maconochie I, Wyckoff MH, et al. 2019 international consensus on cardiopulmonary resuscitation and emergency cardiovascular care science with treatment recommendations. Resuscitation 2019;145:95_150

7. Olai $\mathrm{H}$, Thorneus $\mathrm{G}$, Watson $\mathrm{H}$, et al. Meta-analysis of targeted temperature management in animal models of cardiac arrest. Intensive Care Med Exp 2020;8:3

8. Lascarrou JB, Merdji H, Le Gouge A, et al. Targeted temperature management for cardiac arrest with nonshockable rhythm. N Engl J Med 2019;381:2327 -37

9. Lee BK, Cho IS, Oh JS, et al. Continuous neuromuscular blockade infusion for out-of-hospital cardiac arrest patients treated with targeted temperature management: a multicenter randomized controlled trial. PLOS ONE 2018;13:e0209327

10. Francois B, Cariou A, Clere-Jehl R, et al. Prevention of early ventilator-associated pneumonia after cardiac arrest. N Engl J Med 2019;381:1831-42 